\title{
Pengaruh Model Pembelajaran Word Square Berbasis Tri Kaya Parisudha Terhadap Hasil Belajar IPA
}

\author{
Gd. Roni Cahyana1*, Dewa Nyoman Sudana ${ }^{2}$ \\ 1,2 Jurusan PGSD, FIP Universitas Pendidikan Ganesha Singaraja, Indonesia
}

\author{
A R T I C L E I N F O \\ Article history: \\ Received 10 February \\ 2019 \\ Received in revised form \\ 09 March 2019 \\ Accepted 15 April 2019 \\ Available online 25 May \\ 2019 \\ Kata Kunci: \\ hasil belajar, IPA, Word \\ Square, Tri Kaya Parisudha \\ Keywords: \\ Learning achievement \\ Science, Word Square, Tri \\ Kaya Parisudha.
}

\begin{abstract}
A B S T R A K
Penelitian ini bertujuan untuk mengetahui pengaruh yang signifikan hasil belajar IPA antara siswa yang dibelajarkan model pembelajaran Word Square berbasis Tri Kaya Parisudha dan siswa yang tidak dibelajarkan model pembelajaran Word Square berbasis Tri Kaya Parisudha pada siswa kelas V di SDN Gugus 6 Sutasoma Kecamatan Kubutambahan. Jenis penelitian ini termasuk penelitian eksperimen semu. Populasi penelitian ini adalah seluruh siswa kelas $V$ di SDN Gugus 6 Sutasoma Kecamatan Kubutambahan yang berjumlah 141 siswa, sampel penelitian ini adalah siswa kelas V di SD Negeri 5 Tajun yang berjumlah 14 siswa dan siswa kelas $V$ di SD Negeri 6 Tajun yang berjumlah 16 siswa. Data dianalisis menggunakan metode tes, instrumennya tes hasil belajar IPA dan bentuk tesnya yaitu tes pilihan ganda. Data yang dianalisis menggunakan teknik analisis statistik deskriptif dan analisis statistik inferensial yaitu uji-t. Nilai rata-rata kedua kelas, yaitu kelas eksperimen $=23,64$ sedangkan kelas kontrol $=16,25$.
\end{abstract}

Hasil analisis data menunjukkan thitung $=5,28>$ tabel $=2,048$. Berdasarkan hasil penelitian dapat disimpulkan bahwa terdapat pengaruh model pembelajaran Word Square berbasis Tri Kaya Parisudha terhadap hasil belajar IPA siswa kelas V SDN Gugus 6 Sutasoma Kecamatan Kubutambahan Tahun Pelajaran 2017/2018.

\begin{abstract}
A B S T R A C T
This study aimed at investigating whether or not there was a significant effect on science learning achievement of students who were taught by using Word Square learning model based on Tri Kaya Parisudha and who were not taught by using Word Square learning model based on Tri Kaya Parisudha in the fifth grade students at SDN Gugus 6 Sutasoma Kubutambahan Sub-District in accademic year 2017/2018. This study was a quasi-experimental research. The population of this study was the 141 students of fifth grade students at SDN Gugus 6 Sutasoma Kubutambahan Subdistrict. The research sample were 14 students of the fifth grade students at SD Negeri 5 Tajun and 16 students of the fifth grade students in SD Negeri 6 Tajun. The data were collected by using test method, the instrument was science learning achievement test and used in the form of multiple choice test. The obtained data were analyzed by using descriptive statistical analysis techniques and inferential statistical analysis which was t-test. The average value of the two classes, namely the experimental group was 23.64 while the control group was 16.25. The result of data analysis showed that thitung $=5.28>t_{\text {table }}=2.048$. Based on the results of this study, it can be concluded that there was an effect of Word Square-learning model based on Tri Kaya Parisudha on students' science learning achievement of the fifth grade students at SDN Gugus 6 Sutasoma Kubutambahan Sub-district in academic year 2017/2018.
\end{abstract}

\section{Pendahuluan}

Suatu rumusan nasional Undang-Undang Republik Indonesia No. 20 Tahun 2003 tentang Sistem Pendidikan Nasional (Suardi, 2012: 210) Pendidikan adalah usaha sadar dan terencana untuk

Copyright ( Universitas Pendidikan Ganesha. All rights reserved. 
mewujudkan suasana belajar dan proses pembelajaran agar peserta didik secara aktif mengembangkan potensi dirinya untuk memiliki kekuatan spiritual keagamaan, pengendalian diri, kepribadian, kecerdasan, akhlak mulia, serta keterampilan yang diperlukan dirinya, masyarakat, bangsa dan negara.

Dalam (Purwanto, 2014: 23) dikemukakan pendapat dari Ki Hadjar Dewantara bahwa pendidikan sebagai daya upaya untuk memajukan perkembangan budi pekerti (kekuatan batin), pikiran (intelek) dan jasmani anak-anak. Maksud dari pernyataan tersebut adalah supaya kita dapat memajukan kesempurnaan hidup, yaitu kehidupan dan penghidupan anak-anak, selaras dengan alamnya dan masyarakatnya.

Hamalik (2006: 3), "Pendidikan adalah suatu proses dalam rangka mempengaruhi peserta didik supaya mampu menyesuaikan diri sebaik mungkin dengan lingkungannya, dan dengan demikian akan menimbulkan perubahan dirinya yang memungkinkannya untuk berfungsi dalam kehidupan masyarakat."

Berdasarkan pemaparan dari para ahli, jadi dapat disimpulkan bahwa pendidikan adalah suatu usaha sadar dan sistematis untuk mempengaruhi seseorang agar dapat mengubah taraf hidup atau untuk kemajuan lebih baik.

Suardi (2012: 213), Undang-Undang No. 20 Tahun 2003 tentang Sistem Pendidikan Nasional, Fungsi Pendidikan Nasional dirumuskan kembali sebagai berikut. Pendidikan nasional berfungsi mengembangkan kemampuan dan membentuk watak serta peradaban bangsa yang bermartabat dalam rangka mencerdaskan kehidupan bangsa, bertujuan untuk berkembangnya potensi peserta didik agar menjadi manusia yang beriman dan bertakwa kepada Tuhan Yang Maha Esa, berakhlak mulia, sehat, berilmu, cakap, kreatif, mandiri, dan menjadi warga negara yang demokratis serta bertanggung jawab.

Sekolah sebagai suatu lembaga pendidikan formal, secara sistematis merencanakan bermacammacam lingkungan, yakni lingkungan pendidikan yang menyediakan berbagai kesempatan bagi peserta didik untuk melakukan berbagai kegiatan belajar. Dengan berbagai kesempatan belajar itu, pertumbuhan dan perkembangan peserta didik diarahkan dan didorong ke pencapaian tujuan yang dicita-citakan. Lingkungan tersebut disusun dan ditata dalam suatu kurikulum, yang pada gilirannya dilaksanakan dalam bentuk proses pembelajaran. Istilah kurikulum berasal dari bahasa latin, yakni "Curriculae" artinya jarak yang harus ditempuh oleh seorang pelari.

Melakukan perubahan dalam kurikulum merupakan salah satu upaya pemerintah dalam meningkatkan mutu pendidikan. Pemerintah Indonesia dari tahun 1994 sampai sekarang telah melakukan perubahan kurikulum sebanyak dua kali, dari kurikulum 1994 menjadi kurikulum berbasis kompetensi (KBK), kemudian yang terakhir kurikulum tingkat satuan pendidikan (KTSP). KBK yang telah direvisi melalui KTSP menuntut perubahan paradigma dalam pendidikan dan pembelajaran, khususnya pada jenis pendidikan formal. Perubahan tersebut harus diikuti oleh guru sebagai orang yang berperan penting serta bertanggung jawab atas penyelenggaraan pendidikan di sekolah. Selain itu keahlian guru juga sangat menentukan mutu pendidikan, guru yang mampu mengelola kelas dengan baik serta dapat memilih berbagai jenis model, metode, dan teori yang baik maka akan dapat meningkatkan kualitas siswa dalam menerima dan memahami suatu pembelajaran. Peran guru hendaknya bisa menciptakan kondisi belajar yang kondusif, di mana guru hendaknya mampu menentukan strategi pembelajaran yang tepat, dan mempertimbangkan karakteristik siswa, karakteristik bahan ajar, serta sarana penunjang.

Pemerintah sudah melakukan berbagai upaya untuk meningkatkan kualitas pendidikan di Indonesia, mulai dari pembangunan gedung-gedung sekolah, pengadaan sarana prasarana pendidikan, pengangkatan tenaga kependidikan sampai pengesahan undang-undang sistem pendidikan nasional serta undang-undang guru dan dosen. Namun, upaya yang telah dilakukan masih belum optimal dapat meningkatkan kualitas pendidikan. Siswa masih dirasa kurang terlibat aktif dalam proses pembelajaran, guru sebagai fasilitator bertugas harus menciptakan proses pembelajaran yang menarik agar dapat meningkatkan hasil belajar siswa, khususnya pada pembelajaran IPA.

Pendapat H.W Fowler (dalam Trianto, 2011: 136), IPA adalah pengetahuan yang sistematis dan dirumuskan, yang berhubungan dengan gejala-gejala kebendaan dan didasarkan terutama atas pengamatan dan deduksi.

Penggunaan model pembelajaran sangatlah membantu dalam proses pembelajaran. Guru dituntut tidak hanya mampu menguasai materi yang akan diajarkan, namun guru juga harus mampu menggunakan berbagai jenis model untuk mendorong minat peserta didik dalam mengikuti proses pembelajaran. Adanya sebuah model yang diterapkan saat pembelajaran bisa menunjang aktivitas pembelajaran siswa di kelas, sehingga guru berharap siswa lebih terfokus dan lebih tertarik mengikuti pembelajaran. Joyce \& Weil (dalam Rasana, 2009:1) mendefinisikan model pembelajaran sebagai model yang dapat dipergunakan untuk menciptakan kondisi belajar.

Selain menerapkan model pembelajaran, guru juga harus mampu mengembangkan sebuah media pembelajaran. Media pembelajaran menunjang adanya aktivitas pembelajaran di kelas. Media pembelajaran sebagai pendukung saat guru menerapkan sebuah model, dengan menggunakan media siswa akan menjadi semakin tertarik untuk mengikuti proses pembelajaran. Guru diminta harus kreatif 
dalam membuat atau mengembangkan sebuah media pembelajaran. Pendapat Miarso yang dikemukakan dalam buku (Tegeh, 2009:8) bahwa media belajar adalah segala sesuatu yang dapat digunakan untuk merangsang pikiran, perasaan, perhatian, dan kemauan siswa sehingga dapat mendorong terjadinya proses belajar pada diri siswa.

Selain itu, guru juga diharapkan mampu menerapkan kearifan lokal dalam proses pembelajaran seperti Tri Kaya Parisudha. Tri Kaya Parisudha terdiri dari tiga kata yaitu Tri yang berarti tiga, Kaya yang berarti perbuatan atau prilaku dan Parisudha yang berarti amat disucikan. Bagian-bagian dari Tri Kaya Parisudha yaitu Kayika (berbuat yang baik), Wacika (berkata yang baik), dan Manacika (berpikir yang baik).

Berdasarkan wawancara yang telah dilakukan terkait pembelajaran IPA siswa kelas V SDN Gugus 6 Sutasoma, bahwa terdapat masalah yang di temukan salah satunya adalah hasil belajar siswa yang masih rendah. Para siswa kurang aktif saat mengikuti pembelajaran.

Berdasarkan observasi yang telah dilakukan di SDN Gugus 6 Sutasoma Kecamatan Kubutambahan Kabupaten Buleleng, ditemukan bahwa dalam pembelajaran IPA masih banyak siswa yang mengalami kesulitan dalam pembelajaran. Berkaitan dengan hal tersebut, banyak faktor yang memengaruhi salah satunya pelaksanaan pembelajarannya masih bersifat "teacher centred" atau pembelajaran yang masih berpusat pada guru. Dalam hal ini, peran siswa adalah sebagai penerima informasi yang diberikan oleh guru. Kesempatan siswa untuk mengembangkan kemampuan sesuai dengan bakat dan minatnya menjadi terbatas karena proses pembelajaran sepenuhnya diatur dan ditentukan oleh guru. Guru juga belum menerapkan model pembelajaran serta media pembelajaran untuk menunjang proses pembelajaran. Cara pembelajaran yang demikian dapat membuat siswa pasif dan kurang semangat untuk mengikuti pembelajaran, itu terlihat dari kurangnya antusias siswa dalam menjawab pertanyaan yang diberikan oleh guru, hanya ada beberapa siswa yang antusias dalam mengikuti pembelajaran. Kurangnya penerapan model dan media saat pembelajaran dapat menghilangkan perhatian siswa terhadap pembelajaran. Perhatian menurut Gazali (dalam Slameto, 2003: 56) adalah keaktifan jiwa yang dipertinggi, jiwa itu pun semata-semata tertuju kepada suatu obyek (benda/hal) atau sekumpulan objek. Jika bahan pelajaran tidak menjadi perhatian siswa, maka timbullah kebosanan, sehingga siswa tidak lagi suka belajar. Melalui pencatatan dokumen di peroleh data hasil UAS masih dirasa kurang dan harus ditingkatkan. Dapat dilihat pada tabel berikut.

Tabel 1. Nilai Ulangan Akhir Semester 1 IPA Siswa Kelas V SDN Gugus 6 Sutasoma Kecamatan Kubutambahan Kabupaten Buleleng Tahun Pelajaran 2017/2018

\begin{tabular}{|c|c|c|c|c|c|c|c|}
\hline \multirow[t]{2}{*}{ No. } & \multirow[t]{2}{*}{ Nama Sekolah } & \multirow[t]{2}{*}{$\begin{array}{l}\text { Jumlah } \\
\text { Siswa }\end{array}$} & \multirow[t]{2}{*}{ KKM } & \multicolumn{2}{|c|}{$\begin{array}{c}\text { Siswa yang } \\
\text { Mencapai KKM }\end{array}$} & \multicolumn{2}{|c|}{$\begin{array}{c}\text { Siswa yang Tidak } \\
\text { Mencapai KKM }\end{array}$} \\
\hline & & & & Siswa & $\%$ & Siswa & $\%$ \\
\hline 1 & SD Negeri 1 Tajun & 27 & 70 & 27 & 100 & 0 & 0 \\
\hline 2 & SD Negeri 2 Tajun & 23 & 70 & 20 & 86,95 & 3 & 13,04 \\
\hline 3 & SD Negeri 4 Tajun & 31 & 68 & 31 & 100 & 0 & 0 \\
\hline 4 & SD Negeri 5 Tajun & 14 & 70 & 6 & 42,85 & 8 & 57,14 \\
\hline 5 & SD Negeri 6 Tajun & 16 & 69 & 7 & 43,75 & 9 & 56,25 \\
\hline 6 & SD Negeri 1 Tunjung & 10 & 60 & 10 & 100 & 0 & 0 \\
\hline 7 & SD Negeri 2 Tunjung & 20 & 67 & 4 & 20 & 16 & 80 \\
\hline & Rata-rata & & 67,71 & 15 & 80 & 5,14 & 20 \\
\hline
\end{tabular}

Berdasarkan nilai ulangan akhir semester (UAS) IPA kelas V SDN di Gugus 6 Sutasoma persentase nilai di atas KKM yaitu 80\% siswa yang mencapai KKM dan yang di bawah KKM sebanyak 20\% siswa yang tidak mencapai KKM. Rata-rata keseluruhan nilai sudah hampir memenuhi namun di beberapa sekolah masih mengalami kendala. Jadi belum keseluruhan sekolah mendapatkan nilai di atas KKM lingkup SDN di Gugus 6 Sutasoma Kecamatan Kubutambahan Kabupaten Buleleng.

Ada beberapa hal yang menyebutkan belum maksimal hasil belajar siswa. Pertama, guru tidak menerapkan model dan metode pembelajaran yang bervariasi karena kurangnya pemahaman guru tentang strategi pembelajaran. Kedua, guru belum memanfaatkan media dan menerapkan proses pembelajaran yang berbasis kearifan lokal Tri Kaya Parisudha sehingga siswa kurang perhatian dengan materi yang dibelajarkan, sulit untuk membayangkan apa yang sedang mereka pelajari serta siswa kurang mampu bersikap yang sopan santun. Ketiga, kurangnya interaksi antara guru dengan siswa. itu karena pembelajaran masih bersifat konvensional yang lebih menekankan pada metode ceramah sehingga hasil belajar IPA pun rendah. 
Untuk mengatasi hal tersebut, hendaknya guru mampu untuk melakukan inovasi dalam proses pembelajaran. salah satu cara yang dapat dilakukan dengan merancang pembelajaran yang inovatif. Pembelajaran inovatif yaitu pembelajaran yang melibatkan siswa dalam proses pembelajarannya, yang dikemas dengan aktivitas yang menarik menggunakan model pembelajaran dibantu dengan media. Salah satunya yaitu model Word Square.

Menurut Widodo (dalam Perdani, 2016), model pembelajaran Word Square adalah model pembelajaran yang memadukan kemampuan menjawab pertanyaan dengan kejelian dalam mencocokan jawaban pada kotak-kotak jawaban. Pelaksanaan model pembelajaran ini seperti mengisi teka-teki silang yang tidak asing dikalangan siswa. Bedanya, jawaban teka-teki ini sudah ada namun disamarkan dengan menambahkan sembarang huruf pengecoh. Tujuan huruf pengecoh bukan untuk mempersulit siswa, namun untuk melatih sikap teliti dan kritis siswa. Jika siswa sudah dapat menanggapi secara kritis mengenai soal yang diberikan padanya, dapat mencermati soal tersebut dengan baik, dan dengan ketelitiannya siswa dapat mencocokan jawaban yang ada pada teka-teki dengan pertanyaan yang akan dijawab, maka siswa akan mendapatkan skor atau nilai yang baik. Hal itu tentunya berpengaruh pada meningkatnya hasil belajar siswa.

Menurut (Devina, 2017) menyatakan bahwa ada pengaruh antara penggunaan model pembelajaran word square dibanding yang tanpa menggunakan model pembelajaran word square terhadap kemampuan menjelaskan siswa. Hasil penelitian ini sejalan dengan (Herwandannu, 2018) diketahui bahwa penerapan model pembelajaran Word Square dapat meningkatkan hasil belajar. juga menyatakan bahwa Hasil penelitian menunjukan bahwa prestasi belajar siswa dengan menggunakan model Pembelajaran Word Square mengalami peningkatan setelah model ini diaplikasikan.

Kaitan antara model pembelajaran Word Square dan pembelajaran IPA yaitu dengan menerapkan model pembelajaran ini, maka penerapan materi kepada siswa lebih mudah karena siswa secara tidak sengaja belajar sambil bermain. Model ini sama halnya seperti teka-teki silang, namun dalam pengimplementasiannya siswa dapat berpikir kritis sebelum memilih jawaban yang sudah disediakan. Pembelajaran IPA dengan menggunakan model pembelajaran Word Square dapat membuat siswa berpikir kritis untuk mengasah keterampilan proses dan mengembangkan keterampilan produk.

Kearifan lokal dilihat dari bahasa Inggris terdiri dari dua kata yaitu kearifan (wisdom) dan lokal (local). Wisdom yang berarti kebijaksanaan dan local berarti setempat. Menurut Sukadi, Dkk (2007: 124) "nilai-nilai budaya dan tradisi melandasi kebiasaan orang untuk berinteraksi, berpikir dan belajar. Oleh karena itu dapat dinyatakan bahwa cara berpikir dan cara belajar seseorang dipengaruhi nilai-nilai budaya dan tradisi yang dimiliki". Tri Kaya Parisudha terdiri dari tiga kata yaitu Tri yang berarti tiga, Kaya yang berarti perbuatan atau prilaku dan Parisudha yang berarti amat disucikan. Bagian-bagian dari Tri Kaya Parisudha yaitu Kayika (berbuat yang baik), Wacika (berkata yang baik), dan Manacika (berpikir yang baik). Sukadi, Dkk (2007: 134) Tri Kaya Parisudha yaitu "pengendalian pikiran dengan cara berpikir yang benar, pengendalian perkataan dengan cara berkata yang benar, dan pengendalian perbuatan dengan berbuat yang benar".

Kaitan pembelajaran IPA dengan kearifan lokal Tri Kaya Parisudha sangatlah erat. Ditinjau dari hakekat Tri Kaya Parisudha yaitu Parisudha terdiri dari tiga kata yaitu Tri yang berarti tiga, Kaya yang berarti perbuatan atau prilaku dan Parisudha yang berarti amat disucikan. Bagian-bagian dari Tri Kaya Parisudha dalam konteks IPA yaitu Kayika (berbuat yang benar dan tepat), Wacika (berkata yang benar dan tepat), dan Manacika (berpikir yang benar dan tepat). Kayika (berbuat yang benar dan tepat), ini dimaksudkan untuk pembelajaran IPA siswa harus berbuat sesuai dengan keterampilan proses IPA yang baik dan benar, Wacika (berkata yang benar dan tepat), siswa juga harus berkata sesuai konsep IPA dengan benar dan tepat serta Manacika (berpikir yang benar dan tepat) siswa harus mampu berpikir sesuai dengan konsep IPA yang baik dan benar. Berdasarkan pernyataan di atas, dapat dikatakan bahwa model pembelajaran Word Square berbasis Tri Kaya Parisudha diduga mampu meningkatkan hasil belajar siswa. Untuk membuktikannya, dilakukanlah penelitian eksperimen yang berjudul "Pengaruh Model Pembelajaran Word Square Berbasis Tri Kaya Parisudha terhadap Hasil Belajar IPA Siswa Kelas V SDN Gugus 6 Sutasoma Kecamatan Kubutambahan Tahun Pelajaran 2017/2018".

Berdasarkan uraian di atas, masalah yang dikaji dalam penelitian ini adalah "Apakah terdapat pengaruh hasil belajar IPA antara kelompok siswa yang dibelajarkan dengan model pembelajaran Word Square berbasis Tri Kaya Parisudha dan kelompok siswa yang dibelajarkan dengan model konvensional pada siswa kelas V di SDN Gugus 6 Sutasoma Kecamatan Kubutambahan Tahun Pelajaran 2017/2018?"

Terkait dengan masalah di atas, tujuan dari penelitian ini adalah untuk mengetahui pengaruh hasil belajar IPA yang signifikan antara kelompok siswa yang dibelajarkan dengan model pembelajaran Word Square berbasis Tri Kaya Parisudha dan kelompok siswa yang dibelajarkan dengan model konvensional pada siswa kelas V di SDN Gugus 6 Sutasoma Kecamatan Kubutambahan Tahun Pelajaran 2017/2018. 


\section{Metode}

Penelitian ini dilaksanakan di SD Gugus 6 Sutasoma Kecamatan Kubutambahan. Penelitian ini dilaksanakan pada semester genap tahun pelajaran 2017/2018 dengan menggunakan rancangan desain penelitian non equivalen post-test only control group design. Desain penelitian disajikan pada tabel berikut.

Tabel 2. Desain Penelitian Non Equivalen Post-Tes Only Control Group Design

\begin{tabular}{cccc}
\hline Kelompok & Perlakuan & \multicolumn{2}{c}{ Tes Akhir (Post-Test) } \\
\hline $\mathrm{E}$ & $\mathrm{X}$ & $\mathrm{Q}_{1}$ \\
\hline $\mathrm{K}$ & - & $\mathrm{Q}_{2}$ \\
\hline
\end{tabular}

Keterangan:

E : : Kelompok Eksperimen

K : Kelompok Kontrol

$\mathrm{X}$ :Ada treatment (model pembelajaran Word Square berbasis Tri Kaya Parisudha)

: Tidak menerima treatment (tidak dibelajarkan model pembelajaran Word Square berbasis Tri Kaya Parisudha)

$\mathrm{Q}_{1} \quad$ : Post-Test pada kelompok eksperimen (hasil belajar IPA)

$\mathrm{Q}_{2}$ : Post-Test pada kelompok kontrol (hasil belajar IPA)

Dari pola diatas terlihat bahwa kelompok pertama yang terdiri dari atas kelas merupakan kelas eksperimen (E) yang diberikan perlakuan berupa model pembelajaran Word Square berbasis Tri Kaya Parisudha, dimana setelah diberikan perlakuan, selanjutnya kelompok eksperimen diberikan tes akhir $\left(Q_{1}\right)$. Sedangkan kelompok kedua yang juga terdiri dari satu kelas merupakan kelas kontrol $(K)$ yang tidak diberikan perlakuan treatment atau tidak dibelajarkan dengan model pembelajaran Word Square berbasis Tri Kaya Parisudha, dimana tes akhir $\left(\mathrm{Q}_{2}\right)$ juga diberikan pada kelas kontrol. Selanjutnya, kedua hasil tes tersebut dianalisis untuk mengetahui tingkat keberhasilan perlakuan.

(Agung, 2014: 69) mengemukakan“Populasi adalah keseluruhan objek dalam suatu penelitian". Menurut Sudjana 1975 (dalam Agung, 2014: 69), yang dimaksud populasi ialah totalitas semua nilai yang mungkin, hasil menghitung maupun pengukuran, kuantitatif, maupun kualitatif daripada karakteristik tertentu mengenai sekumpulan objek yang lengkap dan jelas.

Dengan demikian, jumlah populasi penelitian ini adalah keseluruhan subyek penelitian. Populasi dalam penelitian ini adalah seluruh siswa kelas V SD Gugus 6 Sutasoma Kecamatan Kubutambahan Kabupaten Buleleng Tahun Pelajaran 2017/2018.

(Agung, 2014: 69) mengemukakan "sampel ialah sebagian dari populasi yang diambil, yang dianggap mewakili seluruh populasi daan diambil dengan menggunakan teknik tertentu". Sugiyono (2016: 118) mengemukakan bahwa "sampel adalah bagian dari jumlah dan karakteristik yang dimiliki oleh populasi tersebut". Menurut Ali (dalam Agung, 2014:69) teknik yang digunakan mengambil sampel dari populasi disebut "teknik sampling". Margono (2007:125) juga mengemukakan bahwa "teknik sampling adalah cara untuk menentukan sampel yang jumlahnya sesuai dengan ukuran sampel yang akan dijadikan sumber data sebenarnya, dengan memperhatikan sifat-sifat dan penyebaran populasi agar diperoleh sampel yang representatif". Terdapat dua teknik sampling yaitu random sampling dan non random sampling.

Dalam penelitian ini dilakukan dua kali pengundian, yang pertama menentukan dua sekolah yang dijadikan sampel, SD Negeri 5 Tajun dan SD Negeri 6 Tajun muncul pada pengundian sampel yang pertama. Setelah itu dilakukan pengundian kembali untuk menentukan kelas eksperimen dan kelas kontrol. SD Negeri 5 Tajun muncul pertama dan dijadikan kelas eksperimen dan SD Negeri 6 Tajun dijadikan kelas kontrol.

Kelas eksperimen diberikan perlakuan dengan menerapkan model pembelajaran Word Square berbasis Tri Kaya Parisudha dan kelas kontrol diberikan perlakuan dengan menerapkan model pembelajaran konvensional. Pada penelitian ini metode pengumpulan data yang digunakan adalah metode tes pilihan ganda dengan jumlah soal 30 butir. Analisis data yang digunakan dalam penelitian ini yaitu analisis statistik deskriptif. Dalam penelitian ini data disajikan ke dalam bentuk kurva poligon.

Untuk menguji hipotesis maka digunakan analisis data uji-t (Pollend variansi). Ada beberapa syarat yang harus dibuktikan sebelum melakukan uji hipotesis yaitu uji analisis prasyarat yang meliputi uji normalitas sebaran data untuk mengetahui data yang diuji berdistribusi normal dan uji homogenitas varian untuk mengetahui data tersebut bersifat normal dan homogen 


\section{Hasil dan Pembahasan}

Hasil dari analisis data disajikan pada tabel berikut ini :

Tabel 3. Deskripsi Data hasil belajar Kelompok Eksperimen dan Kelompok Kontrol

\begin{tabular}{ccc}
\hline Statistik & Kelas Eksperimen & Kelas Kontrol \\
\hline Banyak Sampel & 14 & 16 \\
Skor Tertinggi & 29 & 24 \\
Skor Terendah & 16 & 10 \\
Mean & 23,64 & 16,25 \\
Median & 24,5 & 15,5 \\
Modus & 25,7 & 14,3 \\
Varians & 15,26 & 14,93 \\
Standar Deviasi & 3,9 & 3,86 \\
\hline
\end{tabular}

Berdasarkan analisis data yang disajikan dalam tabel 3, diketahui hasil belajar IPA siswa kelompok eksperimen lebih tinggi dibandingkan kelompok kontrol. Tinjauan itu dapat dilihat pada rata-rata kelompok eksperimen dan kelompok kontrol. Pada kelompok eksperimen nilai rata-ratanya yaitu 23,64 serta disajikan pada kurva poligon sebaran data kelompok eksperimen merupakan juling negatif yang artinya sebagian skor siswa cenderung tinggi. Gambar disajikan seperti berikut.

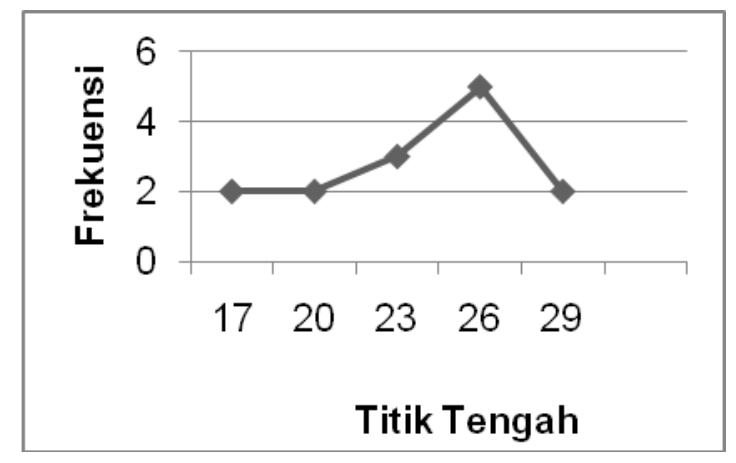

Gambar 1. Kurva Poligon Data Hasil Belajar IPA Kelompok Eksperimen

Pada kelompok kontrol nilai rata-ratanya adalah 16,25 serta disajikan pada kurva poligon sebaran data kelompok kontrol merupakan juling positif yang artinya sebagian skor siswa cenderung rendah. Gambar disajikan seperti berikut.

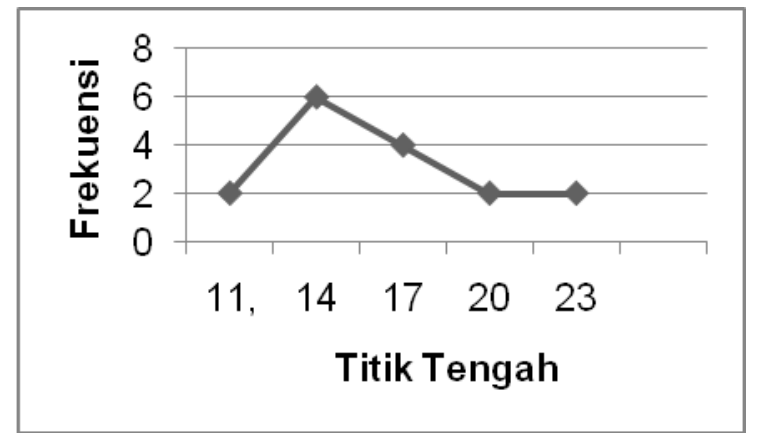

Gambar 2. Kurva Poligon Data Hasil Belajar IPA Kelompok Kontrol

Berdasarkan uji asumsi, diperoleh bahwa data hasil belajar IPA kelompok eksperimen dan kelompok kontrol adalah bersifat normal dan homogen. Setelah itu dilakukan pengujian hipotesis dengan menggunakan uji-t (Sampel Independen Tak-Berkorelasi) dengan rumus polled varians dengan kriteria $\mathrm{H}_{1}$ diterima dan $\mathrm{H}_{0}$ ditolak jika $\mathrm{t}_{\text {hit }}>\mathrm{t}_{\mathrm{tab}}$ dan $\mathrm{H}_{0}$ diterima dan $\mathrm{H}_{1}$ ditolak $\mathrm{t}_{\text {hit }}<\mathrm{t}_{\text {tab }}$ dengan derajat kebebasan $(\mathrm{db})$ $=\mathrm{n}_{1}+\mathrm{n}_{2}-2$. Rangkuman hasil uji hipotesis disajikan pada Tabel berikut. 
Tabel 4. Rangkuman Hasil Uji-t

\begin{tabular}{llllll}
\hline Kelompok & $\mathrm{N}$ & Mean & Varians & thitung & $\mathrm{t}_{\text {tabel }}$ \\
\hline Eksperimen & 14 & 23,64 & 15,26 & 5,28 &, 048 \\
Kontrol & 16 & 16,25 & 14,93 & & \\
\hline
\end{tabular}

Berdasarkan hasil perhitungan uji-t di atas, diperoleh $t_{\text {hit }}$ adalah 5,28. Sedangkan $t_{\text {tab }}$ dengan taraf signifikansi $5 \%$ dan $d b=(14+16-2)=28$ adalah 2,048. Hal ini berarti $t_{\text {hit }}$ lebih besar dari $t_{\text {tab }}\left(t_{\text {hit }}>t_{\text {tab }}\right)$, sehingga $\mathrm{H}_{0}$ di tolak dan $\mathrm{H}_{1}$ diterima, jadi terdapat pengaruh yang signifikan hasil belajar IPA antara kelompok siswa yang dibelajarkan menggunakan model pembelajaran Word Square berbasis Tri Kaya Parisudha dan kelompok siswa yang dibelajarkan tidak menggunakan model pembelajaran Square berbasis Tri Kaya Parisudha.

Faktor yang mempengaruhi hasil belajar siswa pada khususnya dapat dilihat dari keaktifan siswa mengikuti proses pembelajaran, selain itu cara guru dalam mengajar juga mempengaruhi hasil belajar siswa. Berdasarkan hasil uji-t pollend varians $\mathrm{t}_{\text {hit }}=5,28$ dan tab dengan taraf signifikansi $5 \%$ dan $\mathrm{db}=(14$ $+16-2$ ) $=28$ adalah 2,048. Itu menunjukkan bahwa thit lebih besar dari $t_{\text {tab }}$ ( $t_{\text {hit }}>t_{t a b}$ ). Hal ini berarti terdapat pengaruh yang signifikan antara siswa yang mengikuti pembelajaran dengan menggunakan model pembelajaran word square berbasis tri kaya parisudha dan siswa yang mengikuti pembelajaran dengan menggunakan model pembelajaran konvensional.

Terdapat pengaruh yang signifikan antara kelas eksperimen dan kelas kontrol menunjukkan bahwa model pembelajaran word square berbasis tri kaya parisudha dapat mempengaruhi hasil belajar IPA siswa. Hal itu dapat dilihat dari rata-rata dari kelas eksperimen (model pembelajaran word square berbasis tri kaya parisudha) dan kelas kontrol (model pembelajaran konvensional). Rata-rata hasil belajar IPA dari kelas eksperimen yaitu 23,64. Sedangkan rata-rata hasil belajar IPA kelas kontrol yaitu 16,5. Ini berarti rata-rata hasil belajar IPA kelas eksperimen lebih besar dibandingkan dengan rata-rata hasil belajar IPA kelas kontrol ( $\left.\mathrm{M}_{\text {eksperimen }}>\mathrm{M}_{\mathrm{kontrol}}\right)$.

Implementasi pembelajaran yang berbeda menentukan hasil yang berbeda. Perbedaan yang dapat dilihat dari pembelajaran kelas eksperimen dan kelas kontrol yaitu pada langkah dan proses pembelajarannya. (Aqib, 2013:31) menyatakan langkah-langkah pelaksanaan model pembelajaran word square yaitu sebagai berikut. "(1) sampaikan materi sesuai dengan tujuan pembelajaran; (2) bagikan lembaran kegiatan sesuai contoh; (3) siswa disuruh menjawab soal kemudian mengarsir huruf dalam kotak; (4) berikan poin setiap jawab dalam kotak.

Melalui model pembelajaran word square berbasis tri kaya parisudha siswa mampu bersikap, berucap, dan berpikir yang benar dan tepat sehingga mampu mempengaruhi hasil belajar IPA. Sedangkan model pembelajaran konvensional, pembelajaran masih berfokus kepada guru dan siswa cepat merasa jenuh.

Teori dari Hornby (dalam Sudiani, 2014) mengungkapkan bahwa word square adalah sejumlah kata yang disusun sehingga kata-kata tersebut dapat dibaca ke depan dan ke belakang. Selain Hornby, pendapat Kurniasih \& Berlin (2015: 97) mendukung hasil tersebut bahwa, "Word Square adalah model pengembangan dari metode ceramah yang diperkaya dan berorientasi kepada keaktifan siswa dalam pembelajaran. Model ini juga model yang memadukan kemampuan menjawab pertanyaan dengan kejelian dalam mencocokan jawaban pada kotak-kotak jawaban". Penerapan model pembelajaran word square mampu mendorong siswa memahami suatu materi dengan maksimal karena siswa mampu berpikir secara teliti dan kritis. Berpikir secara teliti dan kritis yang dimaksudkan dalam penelitian ini adalah dari LKS word square. LKS word square berbentuk kotak-kotak dan pada kotak-kotak tersebut telah disediakan jawaban. Cara menjawab LKS word square hampir sama seperti menjawab pada teka-teki silang yaitu menjawabnya bisa dengan cara mendatar ataupun menurun. Jika huruf pengecoh atau kotak yang disediakan semakin banyak akan melatih siswa untuk berpikir teliti dan kritis sehingga kedepannya siswa akan terlatih untuk berpikir yang teliti dan kritis untuk menjawab soal sehingga hasil belajarpun dapat meningkat. Berpikir kritis dan teliti sesuai dengan apa yang dikemukakan oleh Kurniasih \& Berlin (2015: 97), salah satunya yaitu merangsang siswa untuk berpikir efektif.

Siswa merasa antusias dalam mengikuti pembelajaran, proses pembelajaranpun akan lebih aktif serta menyenangkan. Sejalan dengan hasil penelitian Perdani (2016) menyatakan pembelajaran word square menyebabkan siswa lebih aktif dan dapat mengembangkan sikap kritis siswa. Berikutnya, Sudiani (2014) dalam penelitiannya juga menyatakan, dengan adanya lembar word square siswa tidak akan merasa jenuh untuk belajar melainkan akan dapat menciptakan suasana yang menyenangkan karena siswa bisa belajar sambil bermain dan melatih siswa untuk disiplin. Proses pembelajaran yang aktif dan menyenangkan mampu meningkatkan hasil belajar siswa. 
Peranan penerapan konsep tri kaya parisudha mendorong siswa agar mampu meningkatkan kedisiplinan siswa. Menurut Sukadi, Dkk (2007:134) Tri Kaya Parisudha yaitu "pengendalian pikiran dengan cara berpikir yang benar, pengendalian perkataan dengan cara berkata yang benar, dan pengendalian perbuatan dengan berbuat yang benar".

Lebih lanjut, Suhardana (2007: 21) menyatakan, Tri Kaya Parisudha diartikan sebagai berpikir baik, berkata baik, dan berbuat baik. Tri Kaya Parisudha berasal dari kata "Tri" yang berarti tiga, "Kaya" berarti prilaku atau perbuatan dan "Parisudha" berarti baik, bersih, suci dan disucikan. Dengan demikian Tri Kaya Parisudha berarti tiga prilaku manusia dalam bentuk piiran, perkataan, dan perbuatan yang harus disucikan.

Bagian-bagian dari Tri Kaya Parisudha dalam konteks IPA yaitu Kayika (berbuat yang benar dan tepat), Wacika (berkata yang benar dan tepat), dan Manacika (berpikir yang benar dan tepat). Dalam penerapan bagian-bagian dari Tri Kaya Parisudha dalam konteks IPA yaitu menurut Marsetio Donosepoetro (dalam Trianto, 2011: 137) IPA dipandang pula sebagai proses, sebagai produk dan sebagai prosedur. Sebagai proses diartikan untuk menemukan pengetahuan baru dengan cara berpikir yang benar dan tepat (Manacika), sebagai produk sebagai hasil proses untuk penyebaran pengetahuan dengan cara berkata serta berbuat yang benar dan tepat (Wacika dan Kayika), dan sebagai prosedur dimaksudkan adalah cara yang dipakai untuk mengetahui sesuatu (riset pada umumnya) yang lazim disebut metode ilmiah (scientific method). Penerapan itu dapat menjadi acuan agar siswa mengikuti kegiatan pembelajaran dengan disiplin dan serius untuk mencapai hasil yang diinginkan.

Berbeda halnya dengan model pembelajaran konvensional yang pembelajaran berfokus kepada guru, guru mendominasi pembelajaran tanpa adanya pembelajaran yang multi arah. Coleman (Whitaker, 1989 dalam Rasana, 2009:18) mengatakan bahwa pembelajaran konvensional merupakan asimilasi informasi dengan ciri-ciri sebagai berikut: (1) pemerolehan informasi, (2) pengorganisasian informasi menjadi prinsip umum, penggunaan prinsip-prinsip umum pada kasus-kasus yang bersifat spesifik, dan penerapan prinsip umum pada keadaan-keadaan baru. Hal ini menunjukkan bahwa guru adalah sumber informasi. Sumber informasi tersebut sangat mempengaruhi proses belajar. Sulaeman (dalam Rasana, 2009:18) mengatakan bahwa pembelajaran konvensional merupakan metode yang paling efisien dalam mengajar yang bersifat hafalan (ingatan). Hal ini menunjukkan bahwa ceramah mendominasi kegiatan belajar mengajar yang menekankan hafalan tersebut. Guru yang menerapkan model pembelajaran konvensional atau yang tidak membelajarkan siswanya dengan menggunakan model pembelajaran word square berbasis tri kaya parisudha cenderung menjadi satu-satunya sumber pembelajaran bagi siswanya, itu terjadi karena guru masih menggunakan metode ceramah alam mengajar. Siswa yang hanya menerima pembelajaran dari guru yang menjadi sumber ajarnya akan lebih cepat merasa jenuh, karena pembelajaran yang monoton seperti itu akan membuat siswa tidak aktif sehingga siswa cenderung pasif. Siswa juga perlu diajarkan untuk mampu menggali pengetahuannya sendiri, dengan cara seperti itu siswa akan lebih merasa tertantang dalam pembelajaran dan pada akhirnya siswa akan lebih bersemangat dalam belajar.

Dengan penerapan proses pembelajaran yang berbeda antara pembelajaran yang menerapkan model pembelajaran word square dan pembelajaran yang menerapkan model pembelajaran konvensional dapat mempengaruhi hasil belajar IPA siswa. Hasil penelitian ini sejalan dengan hasil dari beberapa penelitian yaitu penelitian yang dilakukan oleh (Perdani, 2016) menyatakan bahwahasil penelitian menunjukan pembelajaran dengan model Word Square dengan siswa bermotivasi belajar berbeda menyebabkan adanya perbedaan yang signifikan pada hasil belajar IPA siswa kelas IV SD Gugus III Arjuna Kecamatan Negara Kabupaten Jembrana Tahun Pelajaran 2015/2016. Berikutnya penelitian Sudiani (2014) menunjukan bahwa penggunaan model pembelajaran Word Square dengan kovariabel kemampuan berpikir kritis menyebabkan perbedaan yang signifikan hasil belajar IPA siswa kelas V di Gugus III Kecamatan Buleleng tahun pelajaran 2013/2014.

Berdasarkan temuan-temuan yang ada dalam penelitian ini, dapat dinyatakan bahwa kelompok siswa yang dibelajarkan model pembelajaran word square berbasis tri kaya parisudha lebih berpengaruh positif terhadap hasil belajar IPA pada kelas V SD Negeri 5 Tajun dibandingkan kelompok siswa yang dibelajarkan model pembelajaran konvensional pada siswa kelas V SD Negeri 6 Tajun.

\section{Simpulan dan Saran}

Berdasarkan hasil penelitian dan pembahasan di atas, dapat disimpulkan bahwa terdapat pengaruh hasil belajar IPA yang signifikan antara kelompok siswa yang dibelajarkan menggunakan model pembelajaran word square berbasis tri kaya parisudha dan kelompok siswa yang dibelajarkan dengan model pembelajaran konvensional pada siswa kelas V SD Gugus 6 Sutasoma Kecamatan Kubutambahan Kabupaten Buleleng. Hal ini didukung oleh analisis data. Berdasarkan hasil analisis data diperoleh $t_{\text {hit }}=$ 5,28 dan $t_{t a b}=2,048$ (dengan taraf signifikansi $5 \%$ dan $d b=28$ ). Sehingga $t_{\text {hit }}>t_{t a b}(5,28>2,048), H_{0}$ ditolak 
dan $\mathrm{H}_{1}$ diterima. Dari rata-rata (M) hasil belajar IPA, diketahui (M) kelompok eksperimen adalah 23,64 dan (M) kelompok kontrol adalah 16,25. Hal ini berarti Meksperimen $>M_{\text {kontrol. Dengan demikian, model }}$ pembelajaran word square berbasis tri kaya parisudha berpengaruh terhadap hasil belajar IPA siswa kelas V SD Gugus 6 Sutasoma Kecamatan Kubutambahan Kabupaten Buleleng .

Bertolak hasil pembahasan di atas, dapat diajukan saran berdasarkan penelitian yang telah dilakukan yaitu; 1) Kepada Siswa, dengan diterapkan model pembelajaran word square berbasis tri kaya parisudha, siswa diharapkan agar lebih aktif mengikuti proses pembelajaran, membangun pengetahuan sendiri untuk meningkatkan hasil belajar; 2) Kepada Guru, diharapkan lebih berinovasi dalam menggunakan model pembelajaran yang inovatif salah satunya model pembelajaran word square, mampu mengembangkan media-media pembelajaran serta selalu menerapkan pendidikan tentang kearifan lokal salah satunya tri kaya Parisudha agar siswa mampu bersikap, berucap, berpikir yang baik untuk meningkatkan hasil belajar dan kedisiplinan siswa; 3) Kepada Sekolah, diharapkan sebagai pedoman/acuan dalam meningkatkan hasil belajar siswa. Pihak sekolah hendaknya senantiasa memperhatikan fasilitas penunjang pembelajaran serta mampu memotivasi guru dalam penggunaan model pembelajaran yang beragam; dan 4) Kepada Peneliti Lain, penelitian ini dapat dijadikan pedoman dalam penelitian lanjutan yang dilakukan oleh peneliti pemula yang menggunakan model pembelajaran word square berbasis tri kaya parisudha dalam mata pelajaran IPA maupun pada mata pelajaran yang berbeda. Penelitian ini dapat dijadikan bahan pertimbangan untuk perbaikan dan penyempurnaan penelitian selanjutnya.

\section{Daftar Rujukan}

Agung, A. A. G. (2014). Buku Ajar Metodologi Penelitian Pendidikan. Malang: Aditya Media Publishing. Aqib, Z. (2013). Model-model, Media Dan Strategi Pembelajaran Kontekstual (Inovatif). Bandung: Penerbit Yrama Widya.

Devina, A. (2017). Pengaruh Model Pembelajaran Word Square Terhadap Kemampuan Menjelaskan Energi Alternatif dan Kegunaannya Semester 2 Kelas IV SDN Burengan 2 Kota Kediri Ta 2015/2016. Simki-Pedagogia, 1(11).

Hamalik, O. (2006). Kurikulum dan Pembelajaran. Jakarta: Bumi Aksara.

Herwandannu, B. (2018). Penerapan Model Pembelajaran Word Square untuk Menigkatkan Hasil Belajar IPS Siswa Kelas 3 SDN 2 Slempit Kedamean Gresik. JPGSD, 6(12).

Kurniasih, I. B. S. (2015). Model Pembelajaran. Jakarta: Kata Pena.

Margono. (2007). Metodologi Penelitian Pendidikan. Jakarta: PT Rineka Cipta.

Perdani, I. G. A. M. (2016). Pengaruh Model Pembelajaran Word Square terhadap Hasil Belajar IPA pada Siswa Bermotivasi Belajar Berbeda di Kelas IV SD Gugus III Arjuna Tahun Pelajaran 2015/2016. Jurnal Ilmiah Pendidikan Dan Pembelajaran, 4(1).

Purwanto, N. (2014). Pengantar Pendidikan. Yogyakarta: Graha Ilmu.

Rasana, I. D. P. R. (2009). Model-model Pembelajaran. Singaraja: Undiksha Press.

Slameto. (2003). Belajar dan Faktor-faktor yang Mempengaruhinya. Jakarta: PT Rineka Cipta.

Suardi, M. (2012). Pengantar Pendidikan Teori dan Aplikasi. Jakarta Barat: Indeks.

Sudiani, N. L. (2014). Pengaruh Model Pembelajaran Word Square terhadap Hasil Belajar IPA dengan Kovariabel Kemampuan Berpikir Kritis Siswa Kelas V di Gugus III Kecamatan Buleleng Kabupaten Buleleng Tahun Pelajaran 2013/2014. Jurnal Ilmiah Pendidikan Dan Pembelajaran, 2(1).

Sugiyono. (2016). Metode Penelitian Kualitatif, Kuantitatif, dan R\&D. Bandung: Alfabeta.

Suhardana, K. M. (2007). Tri Kaya Parisudha. Surabaya: Paramita.

Sukadi; Dkk. (2007). Belajar dan Pembelajaran (Berorientasi Konten Kearifan Lokal Budaya Bali). Singaraja: Undiksha Press.

Tegeh, I. M. (2009). Media Pembelajaran. Singaraja: Undiksha Press.

Trianto. (2011). Model Pembelajaran Terpadu: Konsep, Strategi, dan Implementasinya dalam Kurikulum Tingkat Satuan Pendidikan. Jakarta: Bumi Aksara. 